\title{
The International Society for Orthodox Church Music 2015: A Travel Essay
}

\author{
RICHARD BARRETT*
}

In June of 2014, I was a participant in Kurt Sander's Pan-Orthodox Liturgical Music Symposium at Northern Kentucky University in the United States. While I was there, a gentleman whose acquaintance I had newly made, one David Lucs, on hand to give a presentation on children's music education, got my attention about the possibility of attending the International Society for Orthodox Church Music's 2015 conference in Joensuu, Finland. I had been a member of the organization for some years but had never worked up the necessary combination of will and wherewithal to attend the meeting. "It's a great experience," David told me. "People come from Greece, Romania, Serbia, and everyplace else, there's a fantastic sense of collegiality, and everybody always learns a lot."

Shortly thereafter, in a moment of synchronicity, Fr. Ivan Moody was encouraging me to submit a paper for the 2015 conference, which was to have a theme of hymnographic creation. "Would a presentation on The Psalm 103 Project be appropriate?" I asked. "Of course!" was Fr. Ivan's immediate reply. I promised to work something up.

When I discussed the matter with the board of The Saint John of Damascus Society, the Orthodox church music organization I work for and that is spearheading The Psalm 103 Project (see related article), the presidentgot excited about the possibility of presenting what we're working on to an international audience, and once I got the word that my paper had been accepted, he was willing to supportthe travel budget for the conference. A sufficient confluence of events having been achieved, I registered and booked a plane ticket.

And so it was that in June of 2015, I hopped planes from Boston to Paris to Helsinki to the Finnish college town of Joensuu, home to University of Eastern Finland, for ISOCM's tenth anniversary conference. David Lucs' promise of international collegiality was almost immediately fulfilled, with Orthodox musicians from all over the world - twenty-two countries - in attendance; there were composers, singers, and scholars from Serbia, Romania, Greece, Finland, Italy, Denmark, Sweden, Portugal, the UK, the USA,

\footnotetext{
* Richard Barrett, PhD Candidate at Indiana University. Address: 41 Cedrus Ave \#1, Boston, MA 02131 USA; e-mail: richardbarrett@johnofdamascus.org
}

RES 7 (3/2015), p. 476-478

DOI: $10.1515 /$ ress-2015-0037 
the Czech Republic, Japan (!), and more, reflecting an incredible diversity of musical idioms and areas of expertise. I came back with books, scores, and recordings by composers and musicians writing and singing in Finnish, Slavonic, and Romanian. I met Jaakko Olkinuora, who is at present the principal person working on composing Byzantine music for the Finnish language. I got to sing with Achilleas Chaldaiakis, renowned virtuoso cantor, Professor of Byzantine Musicology at the University of Athens, and director of the Maestros of the Psaltic Art, an internationally acclaimed Byzantine choir. I held ison for a Byzantine chant concert sung by a choir of Romanian cantors. The Estonian Philharmonic Chamber Choir gave an amazing concert of Orthodox composers such as Arvo Pärt, Alfred Schnittke, Rachmaninoff, and Fr. Ivan Moody. And so on. (I will also note that the sense of sacred musical fraternity was usually cultivated further over beverages well into Joensuu's summer sunlit nights.)

A major difference between ISOCM and most of the Orthodox musical gatherings I've attended in North America is that ISOCM has a decidedly scholarly, rather than pastoral, focus. This is not to the exclusion of the practical concerns by any means; there were workshops, such as Achillea's workshop on medieval Byzantine chant, as well as services throughout to which all attendees could contribute. However, the objective of the conference is not to provide advice on what to do when less than half of your parish choir reads music half as well as you'd like, nor to reinforce any particular national Orthodox musical identity, but rather to provide a venue for Orthodox musicians and scholarsto discuss their work at a professional level. For the 2015 conference, researchers, performers, and composers from all backgrounds, nationalities, and disciplinesexplored the theme of hymnographic creation from diverse and sundry angles - Athonite musical manuscripts, chant traditions from Central Europe to Russia, modern compositions in the Akathistgenre, and even oratorios that take as their source sacred texts such as the Philokalia.

While it seems remarkable to say so from a North American standpoint, ISOCM's Finnish setting makes this scholarly and professional focus possible in large part. Orthodoxy is very much part of the landscape in Finland, being one of two recognized state churches (the Lutheran church being the other), and Joensuu, where the conference takes place, is home to Finland's Orthodox seminary and a central Orthodox parish. From a European and Balkan perspective, it is a relatively short and easy trip to make. Overall, it allows for a very different kind of conversation and atmosphere than what we're generally accustomed to in the States, one that is able to contextualize the different national traditions as livingexpressions of Orthodox Christianity, and it represents a fantastic learning opportunity for all concerned. 
The rest of the American contingent included David, Kurt Sander, Gregory Tucker, Vladimir Morosan, and Helen Levenetz. David, Kurt, and I had an ongoing conversation in which all were very much of the opinion that an event like this needs to happen Stateside in ISOCM's off-years, and care needs to be given to ensure that it happens at such a level of quality that international participants are encouraged to come, much as USA participants are encouraged to come to ISOCM. There has already been one such attempt to do something like this with PSALM in Chicago, 2006, and then Kurt's Pan-Orthodox Liturgical Music Symposium in 2014 is the more recent effort. This appears to be coming to fruition; a 2016 Symposium has been announced as taking place in Minneapolis, Minnesota, co-sponsored by ISOCM with Fr. Ivan Moody as the keynote speaker.

At the same time, for the North American participants in the 2015 conference, it was clear to us that we need to promote more USA participation in ISOCM. It is truly eye-opening to see the level of what's going on in the rest of the world, and it is of immeasurable benefit to us to have the opportunity to see it for ourselves. 